\title{
The Hungarian argumentation culture in the light of modern societies
}

\section{Eszter Deli, Corvinus University of Budapest, Hungary}

\begin{abstract}
:
In our modern times rhetoric and argumentation seem to be outdated studies, however, agreeing with other big thinkers of the field -e.g. Roland Barthes or Thomas O. Sloane- I personally believe that these sciences have got their importance in every age and culture. In Hungary, argumentation is considered to be less important than other sciences, which shows in our country's educational system as well: the argumentation subject can mainly be found in higher education while it rarely appears in domestic institutions at secondary school level. This phenomenon is related to the formation of Hungary's democratic history. As in the XX.th century a dictatorial institution could be observed in Hungary, the freedom of expression and the development of debate culture was not guaranteed. Although our country has been a member of the democratic states for over twenty years, it is still lagging behind the Anglo-Saxon cultures as far as debating goes. In my research I examined three states' argumentation habits (Great-Britain, The USA, China) through an overall comparative approach and found that these advanced countries highlight the importance of argumentation much more than Hungary. In my further researches I would like to realize a field research and also content analysis if there are no language barriers.
\end{abstract}

Keywords: Debate culture, Linguistic approach, Historical factors, Education, Resolving Contradiction, Cultural differences. 


\section{Introduction}

The topic of my research is in connection with different disciplines, as the analysis of argumentation lies somewhere on the bounds of communication science, psychology and philosophy, not only in everyday life but also according to literature. In our modern times argumentation and rhetoric might seem outdated or even obsolete sciences. We have already heard of their decline, some have completely buried them but some people argue the opposite, such as Roland Barthes (who claims in his work The rhetoric of the image that rhetoric is far from certain to be dead), or Thomas O. Sloane who was brave enough to mention the renaissance of rhetoric. ${ }^{1}$ In her work New Rhetoric, Dr. Aczél Petra describes rhetoric as the main determiner of our ways of thinking and speaking, and also the major former of our social relations. ${ }^{2}$ In agreement with these great figures of science I also believe that argumentation- and the closely related persuasion techniques have got their place in every age and every context.

In Hungary, the less meaningful argumentation subject can mostly be found in higher education, it only appears in very few domestic institutions at secondary school level and even if it does, it is either an elective course or part of another school subject. ${ }^{3}$ Nowadays the push back of the inevitable argumentation and our country's historical background has resulted in the birth of a debate culture that is rudimentary and backward compared to advanced democracies. (e.g.: Anglo-Saxon countries)

My previous research and experience suggest that within the Hungarian debate culture a kind of a misunderstanding emerged in connection with the concept of argument, as in our country argument is considered to be the synonym for verbal fight. The appearance of the negative connotation of this word can be considered widespread in our culture, unlike the Anglo-Saxon debate conception in which a more of a collaborative, constructive approach can be observed, which is free of the associative linking of argument and verbal fights.

\footnotetext{
${ }^{1}$ Tan-Műhely- A. Jászó Anna A retorika kutatása és oktatása, Pedagógiai módszertani és közéleti kiadvány 2004 40.o.

2 Aczél Petra- Új Retorika, Közélet, Kommunikáció, Kampány, Kalligram, Pozsony, 2009, 68.o.

${ }^{3}$ Magyar Közlöny, Magyarország hivatalos lapja, 2012.június.4. hétfö, 66.számhttp://www.kormany.hu/download/c/c3/90000/MK_12_066_NAT.pdf 2013.05.13. 11:18
} 
In order to determine the current state of our country's debate culture - after a comprehensive analysis of the argumentation structure- I will now review some of the developed countries' (such as Western Europe, overseas, or from the Far East) argumentative behaviour, observing those factors of these patterns that (in some form) appear in the Hungarian debate culture and those that are entirely missing.

I believe that my endeavours in this regard not only satisfy my own interest but they also represent a kind of social benefit too, as far as I may contribute to the discovery of Hungary's debate culture through my work.

\section{Relevant historical aspects}

The nature and level of debate culture in certain countries are directly related to these countries' social and political system and the formation of their democratic history. It is easy to admit through a simple logical way, that democracies that guarantee the freedom of expression will allow more room for the development of debate culture than dictatorial systems that either limit or sometimes punish the freedom of speech. The following brief historical outlook is called to justify this logical assumption.

The cradle of democracy and also the home of the flourish of rhetoric used to be Greece. The free Athenian citizens had the right to direct participation in public affaires. Within hustings citizens could express their opinion and directly represent their interest. Neither the Athenian democracy nor the Roman Republic conceded the institution of representation in which the voters realize their views and interests through the elected representatives. The institution of hustings evolved during the medieval English development. It is no coincidence that the modern Anglo-Saxon culture of debate is highly superior to the Eastern European countries that were facing a more difficult democratic development. Despite all the critics that hit the British representative democracy (Churchill himself was criticising the system, but found that there is or was not a better solution throughout history) this type of practice proved to be the most democratic. The French Revolution gave hope for the direct democracy's modern idea for a brief moment, but soon it turned out that the system was completely dysfunctional.

It was replaced by the representative democracy that has certain deficiencies (e.g. To what extent does the elected representative act for all the voters interests and views?), but the 
democratic systems have been using this system to date, supplemented by the presence of direct popular representation on referenda and other popular proposals. The current state of the Hungarian debate culture was strongly influenced by the evolution of our democracy. Although our country has been a member of the democratic states for over two decades, our debate culture is still far from theirs due to the XX.th century's dictatorial institution in Hungary.

On the Kádár-era, although it went through significant changes from 1956 to 1988, Aczél György's cultural policies had a great impact. In the "three T-s" (in Hungarian tiltott, türt, támogatott kultúra, which stands for forbidden, tolerated and supported culture) grip the intuition and freedom of the arts were broken during the long years and arts were put to the service of the one-party state. ${ }^{4}$ Censorship also got in the hands of the state. In such an atmosphere it is natural that the general debate culture could not develop at all. People were distrustful with each-other; their opinion was not articulated outside of the circle of the nuclear family and friends, there was no opportunity for an open and civilized debate. This, of course is true in all ex-socialist states' case.

Former President of the Czech Republic Václav Havel said the following about the importance of the right to freedom of expression and opinion-making: "Freedom of expression is the cornerstone of democratic life. It is by the free exchange of ideas among citizens about how they should live together and how they should be governed that we create and sustain the democratic society. So the rights to free association and expression are scarcely less important than the right to live in peace and free from want."

The previous quote also demonstrates what a major role the social and political system has in a country's or the people's debate culture. It is no coincidence that The Netherlands, which occupies a very prominent place in the forefront of the European debate culture, could boast with the most inclusive and integrating immigration policy within Europe. Not only has The Netherlands accepted, given dual citizenship and voting rights to the immigrants that are now more than a fifth of the population, but has also done everything so that the immigrants could preserve their originals culture, even if it was problematic sometimes. In my essay I will not

\footnotetext{
${ }^{4}$ Dupcsik Csaba- Repárszky Ildikó- Történelem IV.Müszaki Könyvkiadó Kft., 2010, 221.o.

${ }^{5}$ http://www.speakerscornertrust.org/library/about-free-speech/
} 
reach out to the debate habits of the Netherlands, but later on I would definitely like to analyse the debate culture of this developed democracy which can be considered one of the strongholds of argumentation.

\section{The topic's existence within literature}

\section{The concept of argumentation:}

As I have already mentioned it in my introduction, in my opinion argumentation is inevitable these days. The person who lives in a community definitely becomes a rhetorician: just think about our every day interactions with our parents, teachers, the shop assistants or the people on the streets. In fact, I might even say that there is no need for verbal communication to meet the tools of argumentation and persuasion: the television is fighting for our spending power by their advertisements, the political parties are trying their best to gain our votes through their campaigns even the billboards are convincing us about the necessity of their product.

However, to make their communication work efficiently and according to will, they have to be familiar with the features, variability and different approaches of arguments. Argumentation itself carries two meanings: on the one hand it is a structural union of statements which indicates the relation of premises and conclusions, and on the other hand it refers to an argumentative action that creates these premise-conclusion relations. According to Perelman and Olbrechts-Tyteca's rhetorical argumentation-based theory, argumentation above all is to convince our environment, while according to Toulmin's conception of epistemic perception argumentation is a procedure (governed by different rules) that is for supporting and justifying claims. Thus, argumentation can only be accepted if the rules are followed and the standpoints are properly proven by the parties of the communicational action. $^{6}$

\section{Linguistic approach}

The origin of the word argumentation can be derived from the Latin word agumentum that represents the fundamental process of reasoning. This word that appears in modern languages (e.g. English: argument, Italian: argomento or German: Argument) consists of the Latin verb arguo and the Latin suffix - mentum, bound to a verb, "refers, in general, to the process of realisation of the action which the verb represents, indicating, in particular, the way and the

\footnotetext{
${ }^{6}$ Margitay Tihamér Az érvelés mestersége, Budapest, Typotex , 2007, 17.o.
} 
means or instruments with which the action is realized". ${ }^{7}$ A good example for the same grammatical composition is documentum (which indicates the tool of informing) monumentum (the tool of remembering) or the word audimentum (the tool of helping), thus the expression that we examined can be considered the tool of reasoning.

\section{Argumentation and Debate}

Argumentation is dealt by three interrelated disciplines: rhetoric, logic and dialectics. Although these three fields historically differ from each other in many ways. The first one, logic has showed a dynamic growth since the XIX.th century (with the intercession of thinkers like De Morgan or Pierce) however the other two disciplines reflected the traditional Greek theories even in the past century, and as for their development it was longer and slower. In recent years people tried to interpret and explain the concept of argumentation, some believed it to be a device to convince the public, but there were also some who presented it as a justification by generally accepted facts. Eemeren and Grootendorst, however, found that the key element of argumentation was to resolve the differences of opinion, which includes the possibility of clarifying views and forming consensual perspectives. This theory was followed by the speech act theory and the summary of logical fallacies. $^{8}$

\section{The Fundamental Norms of Communication}

One can mostly meet argumentative actions and their results in disputes that -for this reasoncan be considered a fundamental situation of argumentation. The most basic theory of disputes is related to the name of Grice, and is the most general principle of communication. The standard norms of the Grice paradigm can be considered valid for every communicational act, thus for reasoning and argumentation as well. Eemeren and others built on the basis of this theory, the so called pragma-dialectical rules' system which is especially valid for reasoning and argumentation.

The communication principles of Grice are as follows:

\footnotetext{
${ }^{7}$ Nathalie Müller Mirza, Anne-Nelly Perret-Clermont Argumentation and education-Theoretical Foundations and Practices, Springer Science+Business Media, LLC 2009, 10.o.

${ }^{8}$ Zemplén Gábor Á. 2006. Érveléselmélet mint filozófia? Magyar filozófiai szemle 50 (3-4) 326.o.
} 
1.) Be informative! (your message should be on the level of your partner's knowledge)

2.) Tell the truth! (your message would never be false or ungrounded)

3.) Be relevant! (your message should always relate to the topic)

4.) Be clear and understandable! (your message should never be ambiguous, confusing or unnecessary)

5.) Try for understanding your partner! ${ }^{9}$

\section{The Types of Debate}

I continue my dissertation with the analysis of the different kinds of dispute. Besides the three main types of dispute we also have to distinguish two subtypes.

The first type of dispute is the well-known quarrel. Quarrel is characterized by intense feelings, a high degree of irrationality and aggressive personal attacks. In this case, the parties by no means seek to find a common position the main goal is rather to release tension and to hurt each other. (At this point I would like to note that in terms of our country's debate culture the mentioned characteristics are typical, neglecting the -later discussed- rules of argumentation.)

Another type of argumentation is the trial, that's most striking feature is that the success of the debate is decided by a third, ideally neutral party. These types of discussions are also lack of rational and logical reasoning it is rather about undermining the other party's honour and trustworthiness. As an example for the trial type of argumentation I would like to highlight the political debates we see on television. In these debates the parties are not trying to persuade each other, but to gain the sympathy of the third party, which is us, voters.

The third and final main type of disputes is the rational or argumentative debate. As the name indicates in these types of discussions the two sides try to support their own and criticise the other's position through rational arguments. It is interesting that this debate will be positively evaluated even if one party failed to convince the other as problems and difficulties related to the subject may crystallize. ${ }^{10}$

\footnotetext{
${ }^{9}$ Margitay Tihamér Az érvelés mestersége, Budapest, Typotex , 2007, 44.o.

${ }^{10}$ Margitay Tihamér Az érvelés mestersége, Budapest, Typotex , 2007, 24-25.o
} 


\section{Pragma-dialectical Rules}

It is therefore essential to explain the ten rules of rational debate that's violation can be considered a logical fallacy. This system of rules indicates the earlier mentioned pragmadialectical theory that's observation (in addition to the norms of Grice) is a sufficient condition for a good debate.

1.) Parties must not prevent each other from advancing standpoints or casting doubt on standpoints. Fallacies that break the rule: argumentum ad baculum, ad hominen, ad misericordiam.

2.) A party that advances a standpoint is obliged to defend it if the other party asks him to do so. Fallacies that break the rule: shift of the burden of proof.

3.) A party's attack on a standpoint must relate to the standpoint that has indeed been advanced by the other party. Fallacies that break the rule: straw-man argumentation.

4.) A party may defend his standpoint only by advancing argumentation relating to that standpoint. Fallacies that break the rule: ignoratio elenchi, ad populum, ad verecundiam, ad misericordiam.

5.) A party may not falsely present something as a premise that has been left unexpressed by the other party or deny a premise that he himself has left implicit. Fallacies that break the rule: attack of an implicit premise.

6.) A party may not falsely present a premise as an accepted starting point nor deny a premise representing an accepted starting point. Fallacies that break the rule: petitio principia, shift of the burden of proof.

7.) A party may not regard a standpoint as conclusively defended if the defence does not take place by means of an appropriate argumentation scheme that is correctly applied. Fallacies that break the rule: negation of prefix, claim of suffix.

8.) In his argumentation, a party may only use arguments that are logically valid or capable of being validated by making explicit one or more unexpressed premises. Fallacies that break the rule: over-generalization, false analogy.

9.) A failed defence of a standpoint must result in the party that put forward the standpoint retracting it, and a conclusive defence of the standpoint must result in the other party retracting his doubt about the standpoint. Fallacies that break the rule: ad ignorantiam. 
10.) A party must not use formulations that are insufficiently clear or confusingly ambiguous and he must interpret the other party's formulations as carefully and accurately as possible. Fallacies that break the rule: in diction fallacy. ${ }^{11} 12$

These rules of the rational debate are often broken and we must also recognise that rational arguments in the classic sense of the word are rarely used in our everyday communication as the parties of the dispute often have other goals rather than solving their disagreement (e.g. quarrel). Knowing them is still essential as one can only attempt to perform a reasonably and logically valid argument which meets the norms of form and content this way.

The three mail types of dispute discussed above (quarrel, trial and rational debate) can be regarded as ideal-types as they do not often appear in this kind of a limited form. It is a lot more common to have a discussion based on the merger of several types of debate, and they may also turn to each other during the argumentation process, for example a rational argument, through the intensification of feelings and emotions can easily turn into a quarrel. However, we can agree that despite the obvious differences between the debates they share one common thing: each type of dispute encourages the resolution of conflict, whether it is an emotional (quarrel) or interest-based (trial) opposition.

\section{Today's British Debate Culture}

The world-known British debate habits are a fundamental pillar of their culture. From school level to political dimensions they use the means of argumentation to discuss issues and create consensus. Both political and lifestyle changes are initiated through argumentation, thus it is no wonder, that active and constructive participation in social life can be observed within the United Kingdom's society. According to Simon Anderson Great-Britain is a nation of wellinformed, educated and conscious individuals who are keen to participate in events and programs around them which provide opportunity to form opinion, respond to these events, or even to question them. ${ }^{13}$ Such acts of communication frequently lead to disputes that are designed to put the subject under consideration and analysis from every aspect.

\footnotetext{
${ }^{11} \mathrm{http}: / /$ www.ditext.com/eemeren/pd.html 2013.08.23 13:52

12 Zemplén Gábor Á. 2006. Érveléselmélet mint filozófia? Magyar filozófiai szemle 50 (3-4) 339.o.

${ }^{13} \mathrm{http}: / / w w w . u p u b l i s h . i n f o / A r t i c l e / T h e-B r i t i s h-D e b a t i n g-C u l t u r e / 586997$ 2013.05.7. 16:18
} 
This motivation and preference for debates triggered the creation of various debating platforms which were not only designed for professionals, academics and the representatives of power but those well-educated and informed people can also express their opinion whose personal, family and work-life are actually affected by the discussed matters. So those people who feel the need to express themselves and their views or to contradict other opinions enjoy debating on these platforms. This represents great importance in the British culture as they believe that expressing opinion and knowing other's views promote open thinking and different approaches on a social level. Therefore, Britain has always encouraged the hold of healthy, limited debate-events. Over time, these forums have grown into huge entities that aren't restricted by geographical bindings. The active use of online discussion forums has become a real trend in Britain and these online communities offer the opportunity to learn about the opinions and perspectives of others and also to develop constructive criticism. The British debate culture has raised to new heights by the creation of online discussion forums. Today, well-known universities also operate discussion forums, such as Cambridge, that's main goal is to spread knowledge further than the institute's walls. A common platform is provided for individuals of different economic, social and educational backgrounds who become community by the sharing of ideas and opinions. The topics of the debates are not limited global issues (e.g. environment, science, history) are more popular than other matters, though. ${ }^{14}$

However we can find other forms of argumentation through the Internet. Davis and Rouzie in their work of Teaching Argumentation through International Internet Conferencing- believe that every rhetoric-based written argumentation's grounding is a kind of a process of communication that's electronic form creates cultural links between the sender and the receiver of the message. These types of distance learning conferences have specifically been designed to provide students with different ideologies an opportunity to discuss matters with students of other cultural backgrounds through discussions, which also helps them expressing opinions and confronting with others within the framework of formal reasoning. The website, named Cultural Contact has been operating for years, connecting students from countries like Ohio, Sweden and South Korea. ${ }^{15}$

\footnotetext{
${ }^{14}$ http://www.ukdebate.co.uk/ 2013.05.07. 16:19.

${ }^{15} \mathrm{http}: / /$ www.bth.se/fou/forskinfo.nsf/all/3bb02a61b0c5d7fdc12568a3002caba8?OpenDocument 2013.05.07 17:00
} 
Through this site, students, highlighting cultural differences, cultural assumptions, political ideologies, and using the argumentative stylistics, may join to a virtual research group in which they can prepare for a certain debate. (They examine the necessary information, facts, arguments and counter-arguments, etc.) They present their argumentation through the site in the form of an argumentative essay. Although students are not required to accept the opinion of the other party, they must seek solutions that are beneficial and acceptable for both parties. As we can see from the upper described methods of online argumentation, The United Kingdom puts great emphasis on developing and maintaining the quality of the debate culture and argumentative behaviour.

However the online appearance of argumentation can not only be observed on online discussion forums and web conferences. The art of reasoning, its currant usage or its effect on the media are hot topics on anonym blogs as well. This last aspect was accurately examined by an unnamed person, who is speaking about argumentation in the culture of hostility, referring to Frank L. Cioffi. According to him the media are ruining those skills of students that necessary to understand or use argumentation in practice, as they are all about selfpromotion and petty squabbles. The author also tells us that the media has polarized the correctness of arguments, there is no more freedom of speech without prejudice, all became part of the good and bad categories. ${ }^{16}$

Therefore it is interesting to observe how significantly the theoretical and practical examination of argumentation is present in the British Society's everyday life. Rhetoric that might seem an outdated science nowadays has its renaissance at the island, where they acknowledge that it is rhetoric that equips us with the techniques of reasoning and persuasion, as well as helping us form an opinion personally or online. The unnamed blog editor also calls attention to the dubious means of rhetorical forms that the media use, such as propaganda or doublespeak. The elimination of these tools is almost impossible, but knowing the potential effects may reduce the manipulation of arguments used in the media for the whole society.

\section{Today's American Debate Culture}

The American debate culture's most significant factors are balance, listening to the other party's opinion and to ensure equal opportunities to both participants in a certain dispute.

\footnotetext{
${ }^{16}$ http://mnipperhumanities.blogspot.hu/2012/03/argumentation-in-culture-of-discord.html 2013.05.07 18:32
} 
These kinds of debate elements help us approach the world and the people in it, build ideal social relations, and resolve contradictions. Therefore, as seen in the British culture, they assume overseas that the best ways to discuss an idea are to prove new hypothesises, resolve contradictions and to present views through debating. Deborah Tannen, however draws our attention to the dangers of public interactions that could go from a rational debate to a quarrel (as seen in Hungary's debate culture), which is increasing with the variety of the opinions. The American professor of linugistics compares social tensions to the conflicts of married couples: as the spouses, also the public has to be able sort out their differences without causing serious damage or mental scarring to their partner.

However, the media is making it harder and harder to keep up the 'fair play' manners in debates, as the most well known printed media are mentioning certain discussion topics in a provocative way, e.g. War on illegal narcotics, Battle of the sexes, etc. Such polarized phrasing is far from cooperative, contructive problem solving and conflict management, it is rather fueling aggression for eachother, limiting our thinking and ways of expression. Tannen puts across that her society's greatest strenghts are to be able to think openly and to express opinions about dubious questions, being creative and collectively intrested in numerous topics. She is teaching this type of objective, open approach to her students in high school debate clubs, where the acquirment of debating skills are encouraged by the competetive environemnt. For students who participate in debates the club guarantees a brand new patois and status system in a new cultural environment, but they also learn how to communicate with their teammates, teachers, parents and friends in an adequate manner, which -in my opinionwould be an example to follow in Hungary's high schools as well.

\section{Today's Chinese Debate Culture}

The linguists and rhetoricians have recognized the links between the traditional view of Chinese society, the fundamental cultural value system and the rhetorical patterns, which are heavily influenced by the classic Chinese argumentative discourse. Yingqin Liu assumes that the current Chinese rhetorical patterns are linked to China's special cultural factors, which are unique in the whole world, according to her assumptions. China has been a densely populated, agricultural state for the last centuries, where the society's survival depends on hard work and peaceful cooperation. This kind of lifestyle does not allow travelling, changes or getting experience, so the individual who makes all decisions is usually the oldest person in a smaller 
community. This method led to today's hierarchical social organization in China, where two people in absolute equality is unimaginable. This type of social structure was not without effect on the use of language, of course: the social hierarchy between the speaker and audience heavily influences the structure of discussion and also its linguistic formation, regarding the direct/indirect use of language.

Another influencing factor is that in Chinese culture people tend to keep up harmony, that's most important method is preserving peace and dignity ('saving face'). In order to maintain social harmony, they have to learn to keep their dignity, to transmit inconvenient news as well as staying obvious. From ancient times to the present, Chinese people are not only taking account of their own dignity, but they try to keep up others', for example they try to avoid verbal dead-ends on both sides, maintaining the respect for each other. Saving face is an often used strategy to avoid conflicts. The purpose of debating in this culture isn't about embarrassing the other participant, but about constructive conflict management and communication.

Of course I am aware of the fact that the inclusion of an oriental culture's analysis would require a lot of new aspects that would call for the comparison of the West and East as well. I however believe that in order to interpret each debate culture's developmental level and cultural tools, global examinations are needed which would allow us to understand each other's communication in today's multi-cultural world. After a comparative analysis of the argumentative habits of western European countries, it will be a great challenge to confront them with a completely different oriental cultural heritage, but in my opinion this will help me understand the structure of argumentation from a totally new aspect.

\section{Methodological Approaches}

Through my research I will attempt to use a kind of a comparative approach which will allow me to confront the Hungarian debate culture with others states' (e.g. Western Europe, overseas, or the Far East) argumentative habits in terms of the significant differences and other factors that can be relevant for our country's argumentative structure.

First of all I will examine the significance and quality of argumentation and rhetoric studies in our country and other states, both on the level of high school and higher education. By 
summerising my data I will get a complex view on the countries' motivation and potential suitability about argumentation; in addition to that Hungary's argumentative status would become measurable in comparison with other countries. After collecting these sorts of general information more specific examinations will follow by using the method of field research. By my English and Dutch-speaking acquaintances I may have the opportunity to observe the members of a foreign debating society and their cultural practices, current topics, behaviours and attitudes personally. Regarding the observer's potential roles (if there are no language barriers) I would choose cooperation within the debate which would allow me getting full experience as well as providing more valid and reliable data since the observed individuals would not know that they are participants of a research and would behave more naturally. Therefore the main advantage of field research is that the observing researcher can be part of all events, however such direct observation may have some disadvantages regarding data recording. To observe all the relevant aspects of the debate processes I will be taking notes of everything which will include my empirical observations and also my interpretations.

In order to consider those countries' debate culture, that are inaccessible for me I will examine the already mentioned online discussion forums as well. In recent years we could see a dramatic increase in terms of access to computers, which made it possible for the user not only to use the content but also to create it or even share it with others. In addition to the ongoing technological innovations a social group has appeared which applies different communication practices due to the effect of the digital world. The consequences of this appear in the motivation and preferences of the members of the society in terms of taking part in a debate. A lot of researches prove that individuals (especially the members of the younger generation) prefer giving their opinion in relation with politics, social activism and responsibility through the Internet. Thus, this argumentational environment (that uses semiotic signs rather than language) has a more and more significant importance.

The examination will be pursued by content analysis that is a methodological tool for recorded human communication resources such as books, journals, laws, songs, or websites. After the sampling -required to the content analysis- I will compare the foreign online debate habits with our country's, highlighting the differences and similarities. The main advantage of content analysis is its time-and cost-effectiveness, also one can do it on their own without having to take part in the analysis personally to provide representative data. It is also risk-free 
which means that data are still accessable and the sample size is expandable if any error is made, unlike in the case of field research, where the repetition of the event may be problematic. As for me the most important advantage of the content analysis is that this method does not involve intervention, which ensures that I may examine the online argumentations and expressed opinion in an unmodified form. Finally I would like to emphasise on last positive feature of this method: as the future subject of my content analysis is the communication process itself, I do not have to fear validity and reliability problems. ${ }^{17}$

\footnotetext{
${ }^{17}$ Earl Babbie A társadalomtudományi kutatás gyakorlata, Hatodik, átdolgozott kiadás, Budapest Kiadó, Budapest 2001, 354.o.
} 


\section{References}

Aczél P., 2009., Új Retorika Közélet, Kommunikáció, Kampány, Pozsony, Kalligram Kiadó

Babbie, E., 2001, A társadalomtudományi kutatás gyakorlata, Budapest, Budapest Kiadó (Hatodik, átdolgozott kiadás)

Dupcsik Cs., Repárszkí I., 2010., Történelem IV.,Müszaki Könyvkiadó Kft.

http://mnipperhumanities.blogspot.hu/2012/03/argumentation-in-culture-of-discord.html http://press.princeton.edu/titles/7086.html

http://www.bth.se/fou/forskinfo.nsf/all/3bb02a61b0c5d7fdc12568a3002caba8?OpenDocumen

$t$

http://www.speakerscornertrust.org/library/about-free-speech

http://www.ukdebate.co.uk

http://www.upublish.info/Article/The-British-Debating-Culture/586997

Jászó, A.A., (szerk.) 2004, Tan-Mühely, A retorika kutatása és oktatása, Pedagógiai módszertani és közéleti kiadvány

Magyar Közlöny, 2012.június.4. hétfö, Magyarország hivatalos lapja, 66.szám http://www.kormany.hu/download/c/c3/90000/MK_12_066_NAT.pdf

Margitay, T., 2007., Az érvelés mestersége, Budapest, Typotex kiadó

Mirza, N.M., - Perret-Clermont, A.N., 2009, Argumentation and education-Theoretical Foundations and Practices, Springer Science+Business Media, LLC

Tannen, D., 1998., The Argument Culture: Stopping America's War of Words. New York, Ballantine

Yingqin Liu, 2007., Cultural Factors and Rhetorical Patterns in Classical Chinese Argumentation, Texas Tech University, Intercultural Communication Studies XVI : 1

Zemplén, G.Á., 2006, Érveléselmélet mint filozófia? Magyar filozófiai szemle, 50 (3-4) 


\section{Prior References}

Adler, Jonathan E., 1996., "Charity, Interpretation, Fallacy." Philosophy and Rhetoric 29.4

Bailin, Sharon., 2003.,"Is Argument for Conservatives? Or, Where Do Sparkling Ideas Come

From?” Informal Logic 23.1

Barton, Ellen L. 1995., "Constrastive and Non-Contrastive Connectives: Metadiscourse

Functions in Argumentation." Written Communication

Beason, Larry. 1995., "Textbooks on Argumentative Writing.” Composition Chronicle

Crosswhite, James. The Rhetoric of Reason. U Wisconsin P

Elster, Jon, ed., 1998., Deliberative Democracy. New York: Cambridge UP

Freeman, James. 1995., "Premise Acceptability, Deontology, Internalism, Justification." Informal Logic

Greene, Stuart. 1995., "Making Sense of My Own Ideas: The Problems of Authorship in a Beginning Writing Classroom.” Written Communication

Johnson, Ralph H. 2000., Manifest Rationality: A Pragmatic Theory of Argument. Mahwah, NJ: Lawrence Erlbaum

Liu, Yameng. 1995., "Rhetoric and Reflexivity." Philosophy and Rhetoric 28.4

Miller, Carolyn R., and Davida Charney. 2008., "Persuasion, Audience, and Argument." Handbook of Research on Writing. Ed. Charles Bazerman. New York: Lawrence Erlbaum

Redfield, Karen A. 1996., "Opening the Composition Classroom to Storytelling: Respecting Native American Students' Use of Rhetorical Strategies.” Perspectives on Written Argument. Ed. Deborah P. Berrill. Cresskill, NJ: Hampton

Spigelman, Candace. 2001., "Argument and Evidence in the Case of the Personal." College English 64.1

Ziman, John M. 1968., Public Knowledge. Cambridge UP 